\title{
Factors Influencing the Trading Behavior of Investors in Capital Market: An Empirical Study on Dhaka Stock Exchange, Bangladesh
}

\author{
Most. Sharmin Sultana ${ }^{1}$, Abul Kalam ${ }^{2}$, Humaira Begum ${ }^{3}$ \\ ${ }^{1}$ (Lecturer, Department of Marketing, University of Barisal, Barisal, Bangladesh) \\ ${ }_{2}^{2}$ (Assistant Professor, Department of Business Administration, Sonargaon University, Dhaka, Bangladesh) \\ ${ }_{3}^{3}$ (Lecturer, Department of Finance and Banking, Hajee Mohammad Danesh Science and Technology University, \\ Dinajpur, Bangladesh)
}

\begin{abstract}
The investors in different categories have different trading behavior. The main contribution of this study is to analyze the buying behavior of investors in the stock markets. There are many factors that have direct or indirect effect on buying behavior of the investors. After reviewing literature and secondary data the researchers identify some driving factors and primary data have been collected and analyzed based on that factor. From the study, the researchers found that Stock dividend, Company news, Earning per share, AGM and EGM affects the buying behavior absolutely and some factors have no effect and Cash dividend, Margin loan, Placement, Net income and Paid up capital affects significantly. The researchers also found that Islamic philosophy does not play any role with share business.
\end{abstract}

Key Words: Buying Behavior, Capital Market, Share Business, and Stock

\section{Introduction}

All the behavior of human beings during the purchase may be termed as 'buyer behavior'. However buyers (investors) are not rational especially in Bangladesh where, sometimes, share price moves without having any recognized reason. All the listed company's shares, which are available to buyers, have a number of alternatives to buy. Investors are faced buying decisions every working day. But not all decisions are treated the same. Some decisions are more complex than others and thus require more effort by the investors to meet their profit ambition. In the share market, buyers may face five types of buying decisions: minor new purchase, minor re-purchase, major new purchase, major re-purchase and only existing share purchase with a view to netting. So, investors should buy the shares systematically by the way of desire to purchase, search for information, analysis alternatives, purchase share, after-purchase evaluation for getting the higher profit and sales of share. At the time of buying share, investors search for information on possible solutions to satisfy own self. The sources used to acquire this information may be from past experience or the buyer may expend considerable effort to locate information from Internet, news, talk show, talk with others or study the different books or articles etc.

Though the share market in Bangladesh is a growing market, it has significant contribution and serving critical needs of raising fund to our most contemporary economy. In the share market, the value of shares purchased equals the value of shares sold. So one parties always in a favorable position to bit the profit or minimize the cost. Without having consciousness and carefulness many investors are investing to this market. For this reason they cannot get proper benefit from it. So this is the time for financial analysis to add their bit to create a sound and competitive investing environment by educating the public on issue to consider when selecting share to purchase. There are many kinds of reasons and factors for increasing and decreasing of share price, some are related with company and some are related with market mechanism. There are two stock exchanges in Bangladesh, Dhaka stock exchange is one of them on which researchers worked. It is a subject of unconditional options that there are lot of factors-economic, political, internal, external, cultural, natural and social have an important role to play in instigating the instantaneous movement that the market experiences. The researchers have conducted this study to find out the influential determinants that affect the buying behavior of investor. This study is about to know whether dividends, Islamic thoughts, retained earnings, AGM, EGM, earning per share, rumors, margin loan, net income, face value, return on investment, goodwill of the company, company news, analysts' report, sentiment, rumors etc. affect the buying behavior. Whether the existing investors consider these determinants before investing or not? The researchers endeavor to find out the best determinants that affect the buying behavior i.e. on what bases investors should select investment portfolio and what is Islamic perspective about share market. 


\section{Rationale of the Study}

Investors have lack of knowledge-fundamental and technical about capital market. As a result, they cannot gain from share market. Beside this, we can't imagine a world where the majority of investors are rational and moral, there investors can make rational behavior and decisions, but they do not have a special ability to do so to buy shares. Yet such irrational behavior may be deeply rooted in the outlook of investor, and attempts to modify such behavior will not succeed easily where investors are more emotional rather than rational. Although it is an important to provide fundamental shares which help meet the investors need, it is also important to educate investors to understand the fundamental concept and practical situation. Thus, it is imperative that investor education be advanced further. There are some determinants which have great impact on share price. How these determinants influence the buying behavior have been shown through the article. Investor buying decision is composed of two parts, buyers owns decision and the factors affecting the decision process. This study has tried to find out logical and practical determinants that affect the buying behavior of investors. Consider the case of a rational investor investing in an active fund which aims to secure a higher rate of return than its benchmarks.

\section{Objectives of the Study}

The study will be guided by the following specific objectives:

- To ascertain the factors those affect the buying behavior of the investors.

- To examine the connectivity of Islamic philosophy with share business.

- To rank the most active forces and suggest some guidelines to the potential investors.

\section{Literature Review}

Literatures provide no unique measure of indicators of stock market development as well as to select some specific factors to buy share. But it can make the relationship with the literature and the research gap. Bayesid and Tanbir (2010) stated in their study that announcement of dividend is considered to be a significant variable for stock price movement. In their study Nasif, (2010) said that the relationship between dividend changes and subsequent earnings is positive but not significant. Both financial analysts and investors commit that dividends are more valuable than capital gains because they are more reliable and hence less risky. The results of the empirical analysis evidences that dividends retained earnings and other determinants have dynamic relationship with market share price.

Hsin and Hsieh (2010) find that attention-driven buying behavior is mitigated by the financial crisis of 2007, which indicates that the buying behavior of investors is less emotional during a period of financial crisis. Beside this the study come across that when investments are running at a loss, rather than realize the loss, investors hold on to their investments in the hope of reducing their losses despite the risk of further losses. Therefore when the price of a security rises and profit is recorded, investors tend to sell the security quickly to realize their profits. However, if the price of a security falls and it is producing a loss, investors tend to postpone the sale of the security and keep holding onto it.

Alemanni and Ornelas (2008) said that after being the major paradigm on finance for a long time, the efficient market paradigm has been challenged by the behavioral approach. One main difference of the behavior approach is that rational investors are often not numerous and powerful enough to keep the market efficient against the so-called noise traders. This type of investor is assumed to have some behavioral biases when trading. Several studies empirically analyze the behavior of investors looking for these biases, grouping them by categories: individual or institutional, foreigner or domestic.

\section{Methodology of the Study}

This study is empirical and analytical in nature. To investigate the influence of share prices on investment decisions by the buying behavior the study used a simple model five point Likert scale and SPSS to identify some factors and to the measure influenced level. Almost all used data has been collected by designing open ended questionnaire from the 60 respondents by the field survey. And secondary data were collected from Dhaka Stock Exchange and from the internet, published articles \& journals. 


\subsection{Inferences from frequency distribution}

\section{Findings and Discussion}

\subsubsection{Cash Dividend}

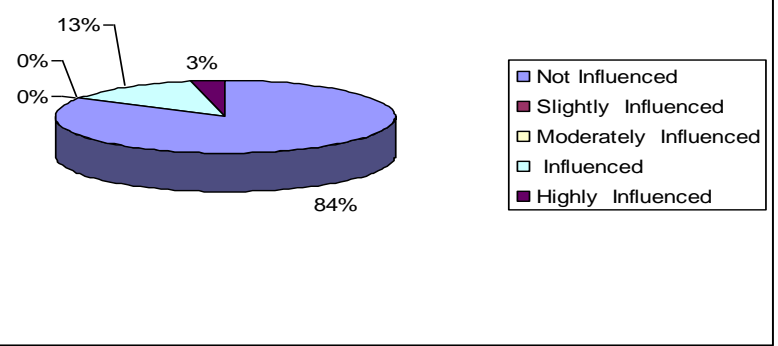

It reveals that $84 \%$ respondent's marked not influenced and only $3 \%$ respondents marked slightly influenced and $13 \%$ are influenced. It is found that cash dividend does not play any vital role for share purchasing behavior.

Source: Field survey, 2015

\subsubsection{Stock Dividend, EPS, P/E Ratio, Goodwill, Company News, AGM \& EGM}

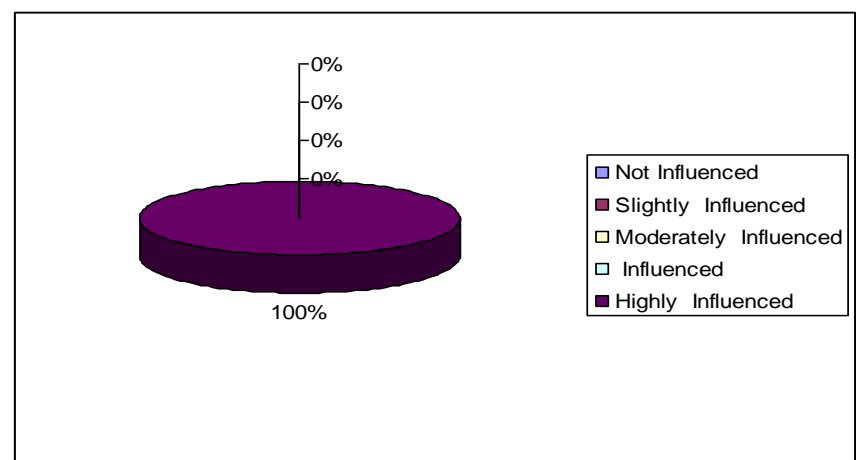

It is found that Stock Dividend, EPS, P/E Ratio, Goodwill, Company News, AGM and EGM play a vital role for share purchasing behavior. It reveals that $100 \%$ respondent's marked highly influenced.

Source: Field survey, 2015

\subsubsection{Paid up Capital, Net Income and Growth of the Company}

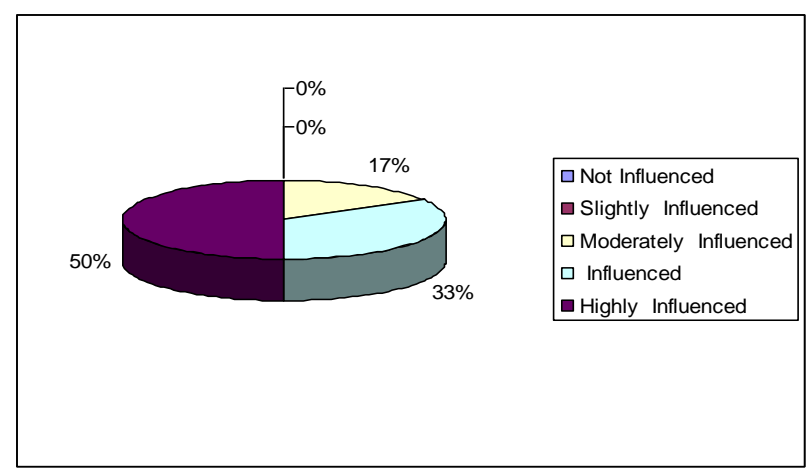

Source: Field survey, 2015

\subsubsection{Outstanding Share}

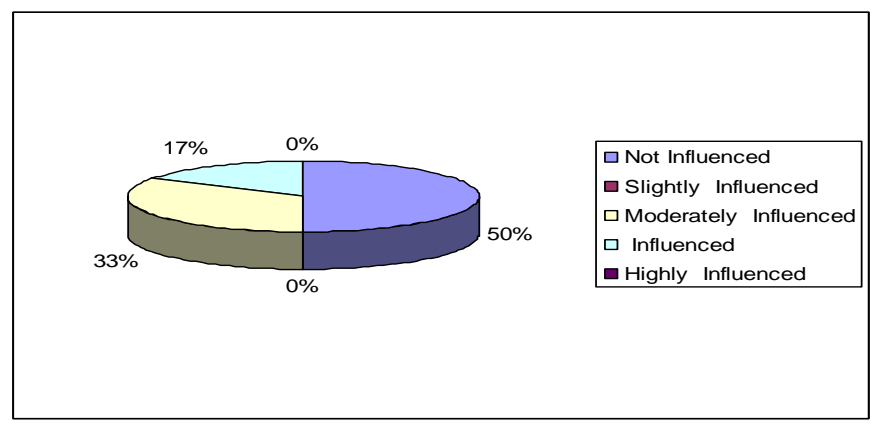

It is found that paid up capital, net income and growth of the company have the effect on share buying behavior. It reveals $50 \%$ respondent's marked highly influenced, 33\% respondent's marked influenced and $17 \%$ are moderately influenced.
It is found that outstanding share does not play any vital role for share purchasing behavior. It reveals that $50 \%$ respondent's marked not influenced and only $33 \%$ respondents marked moderately influenced and $17 \%$ are influenced. 
Source: field survey, 2015

\subsubsection{Retained Earnings}

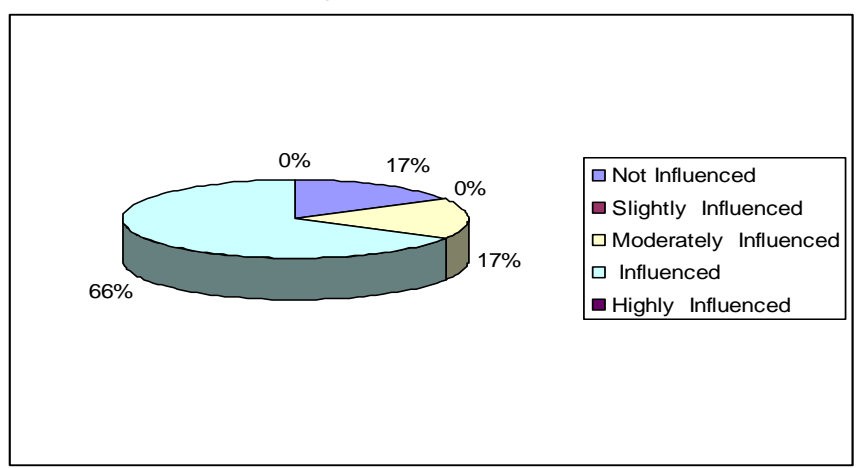

Source: field survey, 2015

\subsubsection{Face Value}

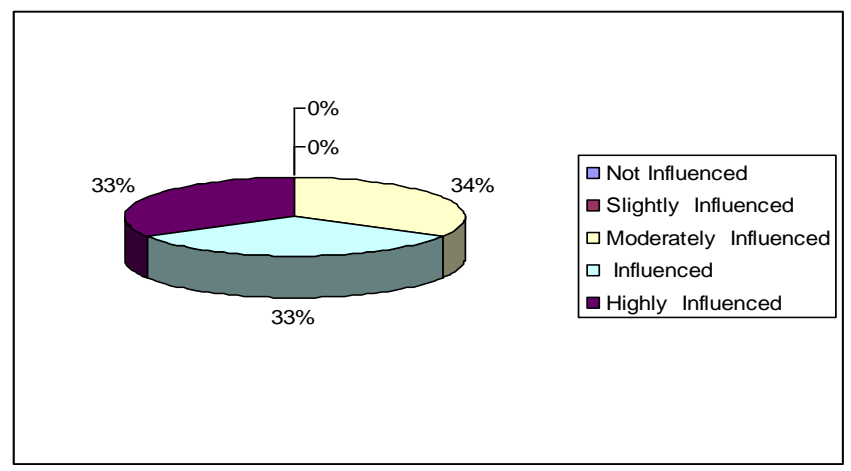

It is found that face value has effects on share purchasing behavior. It reveals that $33 \%$ respondent's marked influenced, $33 \%$ respondent's marked highly influenced and $34 \%$ marked moderately influenced.

Source: field survey, 2015

\subsubsection{ROI}

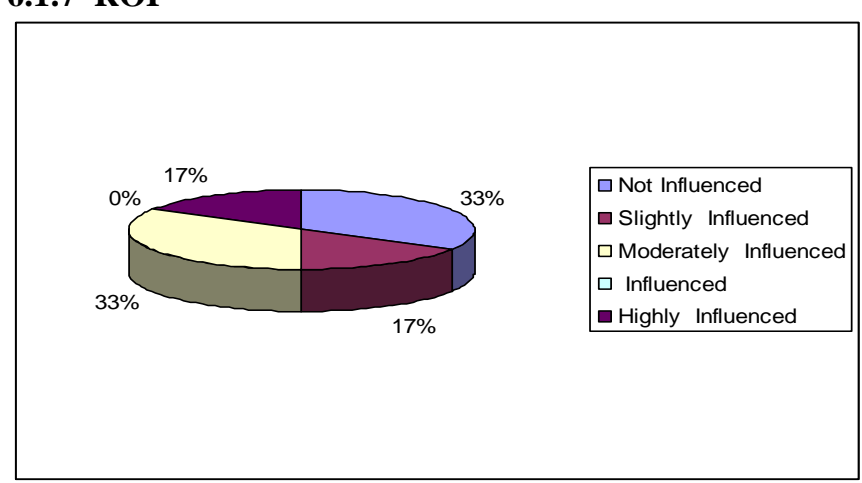

It is found that ROI has mixed effect on share purchasing behavior. It reveals that $33 \%$ respondent's marked not influenced, 17\% respondent's marked slightly influenced, 33\% marked moderately influenced and $17 \%$ marked highly influenced.

Source: field survey, 2015

\subsubsection{Analysts' reports and Rumors}

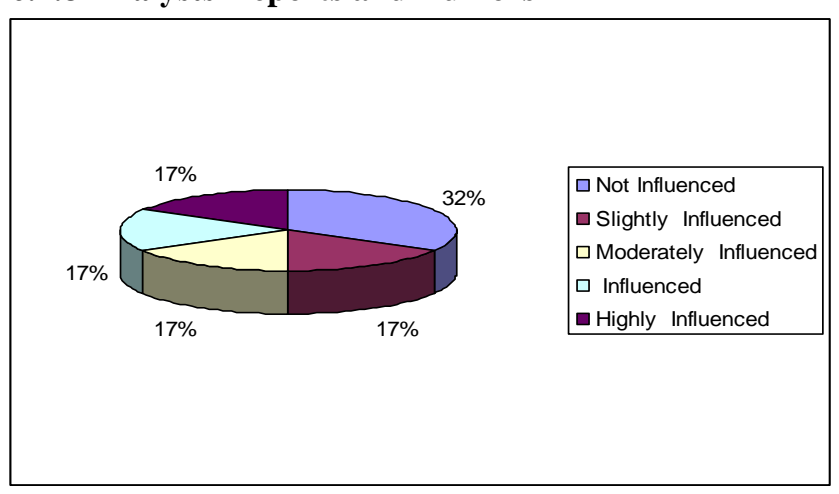

It is found that Analyst Report and Rumors have mixed tendency on share purchasing behavior. It reveals that $32 \%$ respondent's marked not influenced, $17 \%$ respondent's marked slightly influenced, $17 \%$ marked moderately influenced, $17 \%$ marked highly influenced and $17 \%$ marked influenced. 
Source: field survey, 2015

\subsubsection{Record date}

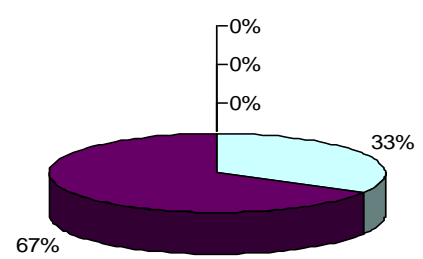

$\square$ Not Influenced

口 Slightly Influenced

$\square$ Moderately Influenced

$\square$ Influenced

Gighly Influenced

Source: field survey, 2015

\subsubsection{Agent's advice}

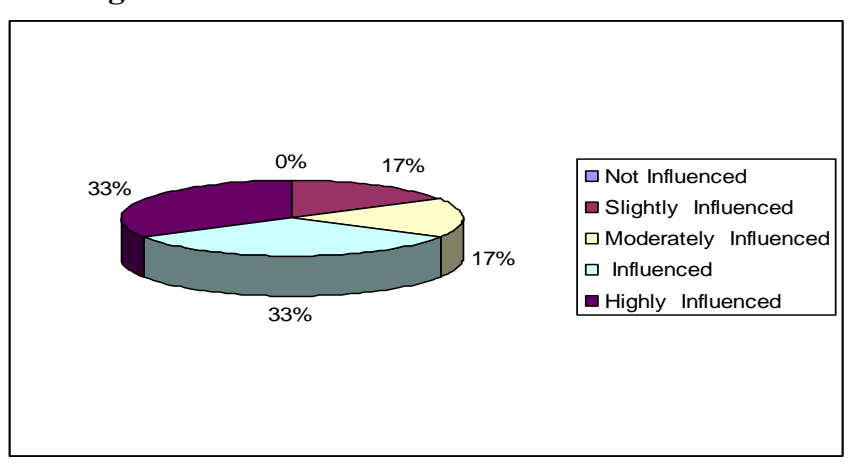

Source: field survey, 2015

\subsubsection{Natural environment}

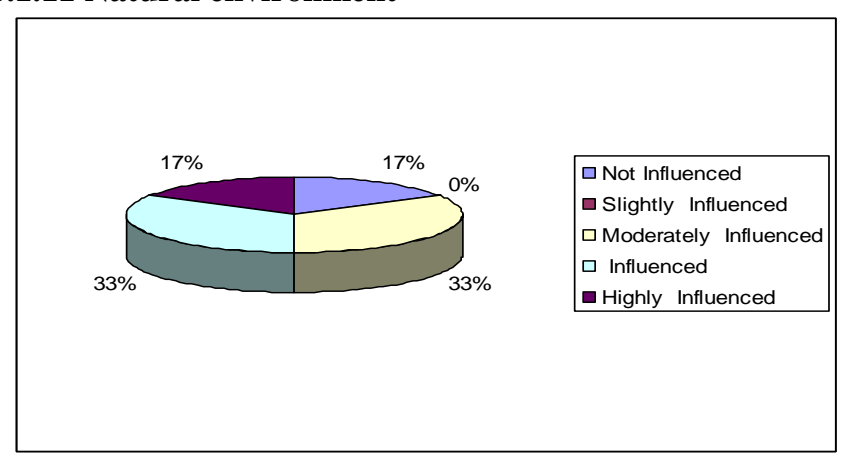

Source: field survey, 2015

\subsubsection{Placement share and Margin loan}

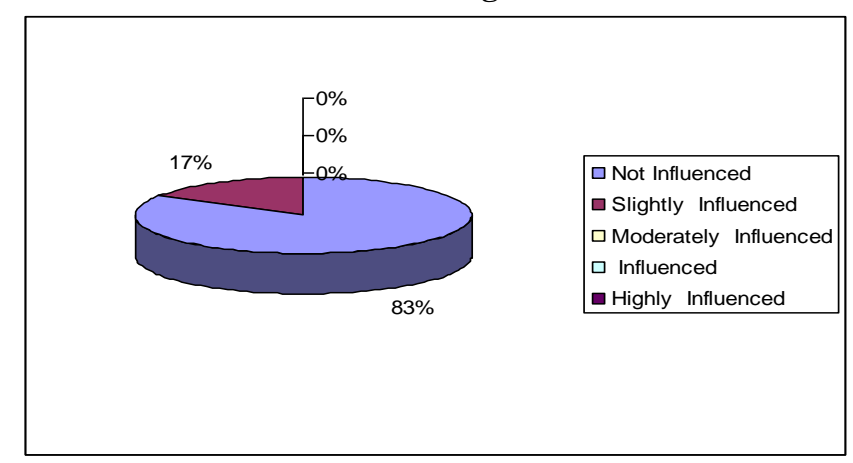

It is found that Record date has effect on share purchasing behavior. It reveals that $67 \%$ respondent's marked highly influenced and 33\% marked influenced.

It is found that Agent's advice has mixed tendency on share purchasing behavior. It reveals that $17 \%$ respondent's marked slightly influenced, $17 \%$ marked moderately influenced, $33 \%$ marked highly influenced and 33\% marked influenced.

It is found that Natural environment has mixed tendency on share purchasing behavior. It reveals that $17 \%$ respondent's marked not influenced, $33 \%$ marked moderately influenced, $17 \%$ marked highly influenced and 33\% marked influenced.

It is found that Placement share and Margin loan do not play a vital role on share purchasing behavior. It reveals that $83 \%$ respondent's marked not influenced and $17 \%$ respondent's marked slightly influenced. 


\subsubsection{Sentiment}
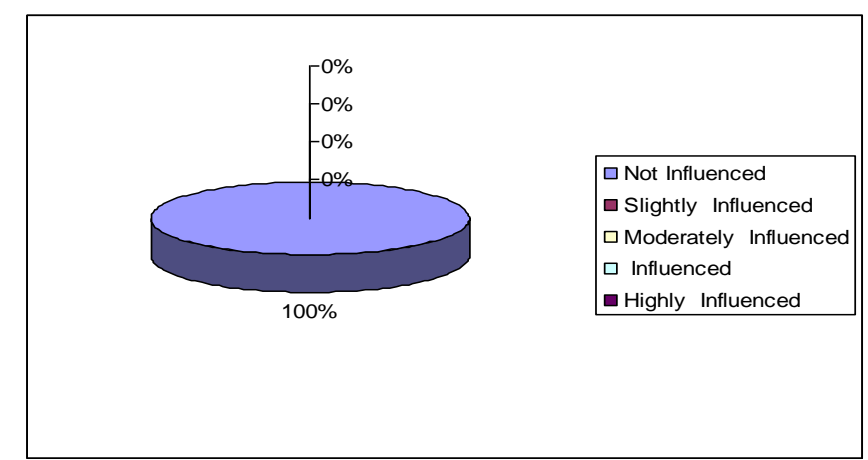

Source: field survey, 2015

\subsection{Inference from Islamic philosophy}

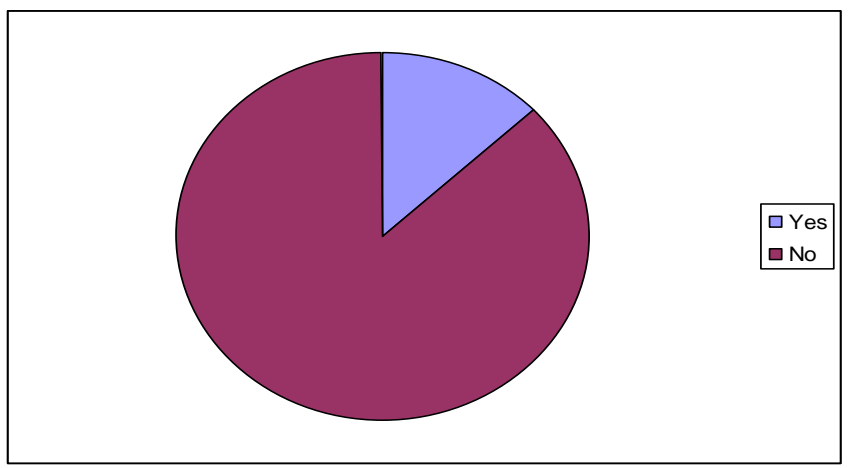

It is found that sentiment has no effect on share purchasing behavior. It reveals that $100 \%$ respondent's marked not influenced.

(a) Do you think Islam is completely adverse with share business?

(b) Do you consider any Islamic thought at the time of purchasing share?

$87 \%$ respondent comment they do not think about Islamic thought and they do not think Islam is completely adverse at the time of buying share and $13 \%$ comment they think about Islamic thought and Islam is completely adverse with share business at the time of buying share.

Source: field survey 2015

\subsection{Descriptive statistics}

Islamic Philosophy: All most all the peoples have religious faith and worthiness to their creator. Among them Islam is the best and complete code of life to serve and survives. In this country most of the people are spiritual in Islam and Muslims are the devoted very carefully and completely. So, it is an important factor to the investor for buying the share and to judge, whether the share is shariah complaint or not.Shariah complaint share is strictly prohibited to trade under Islamic perspective.

Table 6.3.1: Descriptive statistics of different variables
\begin{tabular}{|l|c|c|c|c|c|}
\hline \multicolumn{5}{|c|}{ Descriptive Statistics } \\
\hline & Number & Minimum & Maximum & Mean & Standard Deviation \\
\hline Cash dividend & 60 & 0.00 & 4.00 & 0.53 & 1.21 \\
\hline Stock dividend & 60 & 4.00 & 4.00 & 4.00 & 0.00 \\
\hline EPS & 60 & 4.00 & 4.00 & 4.00 & 0.00 \\
\hline Paid up capital & 60 & 2.00 & 4.00 & 3.33 & 0.75 \\
\hline Outstanding share & 60 & 0.00 & 3.00 & 1.17 & 1.22 \\
\hline Net income & 60 & 2.00 & 4.00 & 3.33 & 0.75 \\
\hline Retained earnings & 60 & 0.00 & 3.00 & 2.33 & 1.11 \\
\hline Face value & 60 & 2.00 & 4.00 & 3.00 & 0.82 \\
\hline P.E /ratio & 60 & 4.00 & 4.00 & 4.00 & 0.00 \\
\hline Return on investment & 60 & 0.00 & 4.00 & 1.50 & 1.40 \\
\hline Co. growth & 60 & 2.00 & 4.00 & 3.33 & 0.75 \\
\hline Goodwill & 60 & 4.00 & 4.00 & 4.00 & 0.00 \\
\hline Co. news & 60 & 4.00 & 4.00 & 4.00 & 0.00 \\
\hline Analyst report & 60 & 0.00 & 4.00 & 1.67 & 1.50 \\
\hline Sentiment & 60 & 0.00 & 0.00 & 0.00 & 0.00 \\
\hline Record date & 60 & 3.00 & 4.00 & 3.67 & 0.48 \\
\hline Rumors & 60 & 0.00 & 4.00 & 1.67 & 1.50 \\
\hline Agent advice & 60 & 1.00 & 4.00 & 2.83 & 1.08 \\
\hline Natural environment & 60 & 0.00 & 4.00 & 2.33 & 1.26 \\
\hline Placement share & 60 & 0.00 & 1.00 & 0.17 & 0.38 \\
\hline AGM \& EGM & 60 & 4.00 & 4.00 & 4.00 & 0.00 \\
\hline
\end{tabular}


Factors Influencing the Trading Behavior of Investors in Capital Market: An Empirical Study on ..

\begin{tabular}{|l|l|l|l|l|l|}
\hline Margin loan & 60 & 0.00 & 1.00 & 0.17 & 0.38 \\
\hline
\end{tabular}

From the above table, it was found that the mean value of stock dividend, EPS, P/E ratio, goodwill of the company, company news, AGM \& EGM and company news influenced buying behavior of the investor absolutely (scored 4 out of 4). Paid up capital, Record date, Net income and company growth strongly influenced (scored more than 3) buying behavior of investors. The rest of the variables do not influenced strongly.

\subsubsection{Inferences from Chi- Square Test}

The chi-square test is performed to test to identify which variables have association with the buying behavior of the investors. Details information was also set in Appendix 1 and 2.

Table 6.3.2: Variables association with the buying behavior of the investors

\begin{tabular}{|c|c|c|c|c|c|c|}
\hline \multirow[t]{2}{*}{ Variables } & \multirow{2}{*}{$\begin{array}{l}\text { Chi-Square } \\
\text { Result }\end{array}$} & \multirow{2}{*}{$\begin{array}{l}\text { Asymp. } \\
\text { Sig. }\end{array}$} & \multirow{2}{*}{$\begin{array}{l}\text { Monte- } \\
\text { Carlo Sig. }\end{array}$} & \multirow{2}{*}{$\begin{array}{l}\text { Degress } \\
\text { of } \\
\text { freedom }\end{array}$} & \multicolumn{2}{|c|}{ 95\% Confidence Interval } \\
\hline & & & & & $\begin{array}{l}\text { Lower } \\
\text { Bound }\end{array}$ & Upper Bound \\
\hline Cash dividend & 68.40 & 0.000 & 0.000 & 2 & 0.000 & 0.049 \\
\hline Paid up capital & 10.00 & 0.007 & 0.000 & 2 & 0.000 & 0.049 \\
\hline Outstanding share & 10.00 & 0.007 & 0.000 & 2 & 0.000 & 0.049 \\
\hline Net income & 10.00 & 0.007 & 0.000 & 2 & 0.000 & 0.049 \\
\hline Face value & 0.00 & 1.000 & 1.000 & 2 & 0.951 & 1.000 \\
\hline Company news & 10.00 & 0.007 & 0.000 & 2 & 0.000 & 0.049 \\
\hline Analyst report & 6.66 & 0.155 & 0.117 & 4 & 0.035 & 0.198 \\
\hline Margin loan & 26.66 & 0.00 & 0.000 & 1 & 0.000 & 0.049 \\
\hline Placement & 26.66 & 0.00 & 0.000 & 1 & 0.000 & 0.049 \\
\hline Rumors & 6.66 & 0.155 & 0.117 & 4 & 0.035 & 0.198 \\
\hline Environment & 6.66 & 0.083 & 0.063 & 3 & 0.000 & 0.079 \\
\hline Agent advice & 6.66 & 0.083 & 0.063 & 3 & 0.000 & 0.079 \\
\hline Retained Earnings & 30.00 & 0.000 & 0.000 & 2 & 0.000 & 0.049 \\
\hline Return on investment & 6.66 & 0.083 & 0.063 & 3 & 0.000 & 0.079 \\
\hline Company growth & 10.00 & 0.007 & 0.000 & 2 & 0.000 & 0.049 \\
\hline
\end{tabular}

From the above table, the result of the chi-square shows that face value, return on investment, analyst report, rumors, agent advice, and environment have no association with the buying behavior. Cash dividend, paid up capital, outstanding share, net income, retained earnings, company growth and record date have association at $\alpha=0.05$. Chi-square test is not possible for the variables EPS, P/E ratio, goodwill of the company, company news, AGM \& EGM and company news because of constant values.

\section{Recommendations}

The researchers have recommended some suggestions to the potential investors that help them to harvest some benefit from the share business. The investors should invest after considering some variables such as stock dividend, P/E ratio, EPS, AGM \& EGM, goodwill. Investors should gather proper knowledge about fundamental analysis as well as technical analysis and purchase frequently traded share with portfolio rather than single one. The investors should be watch dog to harvest benefit from share business. To bit the profit at the time of fluctuation, investors will continue to hold securities if a given fluctuation in price produces a higher expected value, and will sell securities if a given fluctuation in price produces a lower expected value.

Literate investors may follow many calculations of corporate performance when deciding to buy the shares. Investment funds should be developed based on an analysis of investor preferences but not be designed blindly. This can be from simple price earnings ratio to more technical analysis compare Net Assets Value with Market Value Relative Strength Index, Price Earnings Ratio, Simple Moving Average, Exponential Moving Average, and Moving Average Convergence Divergence.

\section{Conclusion}

Most of the investors are not in a position to forecast but they have a good sense of which transaction makes them feel better about investing. This study focused on the determination of influential share price factor and debated the buying behavior of individual investors. Although it is emerging market but Dhaka Stock Exchange in Bangladesh is inefficient in weak form. Beside this, the respondents have no proper knowledge about share market. Therefore, it is very difficult to draw a conclusion. Investors buying behavior may be unduly influenced by the prevailing atmosphere. Making spontaneous decisions based on the prevailing atmosphere results in a tendency to purchase at high prices. The researchers concluded that investors have a strong obsession with purchase price, and tend to sell rapidly after maturing when unit price exceeds purchase 
price. We also concluded that much investor behavior is irrational, and pointed out that, as such, further investor education is necessary.

The researchers identify some variables such as cash dividend, stock dividend, earning per share, paid up capital, outstanding share, net income, face value, P/E ratio, return on equity, margin loan, placement, rumors, environment, agent advice, goodwill, record date, sentiment, AGM and EGM. From the study, the researchers found that stock dividend, company news, earning per share, AGM and EGM affects the buying behavior absolutely, and face value, sentiment, return on asset, analyst report, rumors, agent advice and environment have no effect, and cash dividend, margin loan, placement, net income and paid up capital affects significantly. The researchers also found that Islamic philosophy does not play any role with share business. When investors expect return on investment to be high, the value of purchases will increase. Conversely, when expected return on investment is low, the value of purchases will decrease. Important buying behavior is that they compare investment profit without having any comparative. However, acting on intuition can only lead to the repeating of failures and mistakes. Simply true that one cannot evaluate the performance of a fund without comparing it to benchmarks and other similar funds. So a fund's unit price is low does not imply that it is performing poorly because fund and unit price are not directly related.

\section{References}

[1]. Bayezid, K.M., Ahmed, G. and Tanbir, M., 2010, 'Effect of Dividend on Stock Price in Emerging Stock Market: A study on the Listed Private Commercial Banks in DSE', International journal of Economics and Finance, 4, 52-64.

[2]. Nasif, F., 2010, 'Analysis the Determinants of Market Stock Price Movement: An Empirical Study of Jordanian Commercial Banks', International Journal of Business and Management, 10, 137-147.

[3]. Hsin, Y.Y. and Hsieh. S. F., 2010, 'The Effect of Attention on Buying Behavior During a Financial Crisis: Evidence from the Taiwan Stock Exchange.' Elsevier

[4]. Alemanni, B. and Ornelas J.R.H., 2008, 'Behavior and Effects of Equity Foreign Investors on Emerging Markets', RePEc: bcb: working paper: 159 .

[5]. Abdullah, M.N., Parvez, K. and Khaled, M., 2015, 'Is the Stock Market Overvalued: A Study in the Context of Bangladesh?', Asian Business Review, 1(1), pp.30-36.

[6]. Aziz, M.S.I. and Uddin, M.N., 2015, 'Volatility Estimation in the Dhaka Stock Exchange (DSE) returns by GARCH models'. Asian Business Review, 4(1), pp.41-49.

[7]. Chowdhury, S.S.H., Sharmin, R. and Rahman, A., 2014, 'Effect of sentiment on the Bangladesh stock market returns' available at SSRN 2416223.

[8]. Ouma, W.N. and Muriu, P., 2014, 'The impact of macroeconomic variables on stock market returns in Kenya', International Journal of Business and Commerce, 3(11), pp.1-31.

[9]. Dewri, L.V. and Islam, M.R., 2015, 'Behavioral Analysis of Investors' Attitude towards Dividend Declaration in Developing Country-A Case of Bangladesh', International Journal of Business and Management, 10(11), p.185.

[10]. Hasan, M. and Ahmed, A.A.A., 2014, 'Financial reporting practices in the textile manufacturing sectors of Bangladesh, ABC Journal of Advanced Research, 3(2), pp.57-68.

[11]. Joarder, M.A.M., Ahmed, M.U., Haque, T. and Hasanuzzaman, S., 2014, 'An empirical testing of informational efficiency in Bangladesh capital market', Economic Change and Restructuring, 47(1), pp.63-87.

\section{Website:}

[12]. www.dsebd.org (access date: 10.01.2016)

Appendix-1

\begin{tabular}{|l|c|c|}
\hline $\begin{array}{l}\text { (a) Do you consider any Islamic thought at the time of determining } \\
\text { the share price? }\end{array}$ & Yes & No \\
\cline { 2 - 3 } & $13 \%$ & $87 \%$ \\
\hline (b) Do you think Islam is completely adverse with share business? & $13 \%$ & $87 \%$ \\
\hline
\end{tabular}

Appendix-2

Please select the factors below on the basis of rate of the strength of the factors influence over the buying behavior.[0=Not influenced; 1=Slightly influenced; 2=Moderately Influenced; 3=Influenced; 4= Highly Influenced]

\begin{tabular}{|c|c|c|c|c|c|c|}
\hline $\begin{array}{l}\text { SL. } \\
\text { No }\end{array}$ & Factors & $\begin{array}{c}\text { Not } \\
\text { influenced } \\
(0)\end{array}$ & $\begin{array}{c}\text { Slightly } \\
\text { influenced } \\
(1)\end{array}$ & $\begin{array}{l}\text { Moderately } \\
\text { Influenced } \\
\text { (2) }\end{array}$ & $\begin{array}{c}\text { Influenced } \\
\text { (3) }\end{array}$ & $\begin{array}{c}\text { Highly } \\
\text { Influenced } \\
(4)\end{array}$ \\
\hline 1 & Cash dividend & 50 & 0 & 0 & 8 & 3 \\
\hline 2 & Stock dividend & 0 & 0 & 0 & 0 & 60 \\
\hline 3 & Earnings per share (EPS) & 0 & 0 & 0 & 0 & 60 \\
\hline 4 & Paid up capital & 0 & 0 & 10 & 20 & 30 \\
\hline 5 & Outstanding share & 30 & 0 & 20 & 10 & 0 \\
\hline 6 & Net income & 0 & 0 & 10 & 20 & 30 \\
\hline 7 & Retained earning & 10 & 0 & 10 & 40 & 0 \\
\hline 8 & Face value & 0 & 0 & 20 & 20 & 20 \\
\hline 9 & Price Earnings (P/E) Ratio & 0 & 0 & 0 & 0 & 60 \\
\hline 10 & Return on Investment (ROI) & 20 & 10 & 20 & 0 & 10 \\
\hline 11 & Growth of the industry & 0 & 0 & 10 & 20 & 30 \\
\hline
\end{tabular}


Factors Influencing the Trading Behavior of Investors in Capital Market: An Empirical Study on ..

\begin{tabular}{|l|l|c|c|c|c|c|}
\hline 12 & Goodwill of the company & 0 & 0 & 0 & 0 & 60 \\
\hline 13 & Company news & 0 & 0 & 0 & 0 & 60 \\
\hline 14 & Analyst report & 20 & 10 & 10 & 10 & 10 \\
\hline 14 & Sentiment & 60 & 0 & 0 & 0 & 0 \\
\hline 15 & Record date & 0 & 0 & 0 & 20 & 40 \\
\hline 16 & Agent's advice & 0 & 10 & 10 & 20 & 20 \\
\hline 17 & Natural environment & 10 & 0 & 20 & 20 & 10 \\
\hline 18 & Rumors & 20 & 10 & 10 & 10 & 10 \\
\hline 19 & Placement share & 50 & 10 & 0 & 0 & 0 \\
\hline 20 & AGM,EGM & 0 & 0 & 0 & 0 & 60 \\
\hline 21 & Margin loan & 50 & 10 & 0 & 0 & 0 \\
\hline
\end{tabular}

